\title{
LITHOSTRATIGRAPHY OF THE MIOCENE DEPOSITS IN THE EASTERN PART OF BOROD BASIN (NORTH-WESTERN OF ROMANIA)
}

\author{
MIRELA POPA $^{1}$
}

\begin{abstract}
The paper presents the lithostratigraphic units of the Miocene deposits in the eastern part of Borod Basin. Four lithostratigraphic units were defined (Borod Formation, Cornitel Formation - including Borozel Member - and Beznea Formation) according to the recommendations of the International Stratigraphic Guide.
\end{abstract}

KEYWORDS: lithostratigraphic units, Miocene, Borod Basin, Romania.

\section{INTRODUCTION}

The Neogene Borod Basin is located in the western part of Apuseni Mountains, between Plopiş Mountains in the northern and Pădurea Craiului Mountains in the southern part. The Neogene deposits transgressively overlay the crystalline formations of the Someş Group (Dimitrescu, 1988) (=Someş lithogroup, Balintoni, 1997). The metamorphic rocks constitute most of the Plopiş Mountains but also outcrop as isolated patches in the eastern part of Pădurea Craiului Mountains. The rest of the latter massif is covered by a Permo-Mesozoic of sedimentary rocks.

The basin itself was formed as a result of an extensional tectonic regime along a normal NW-SE oriented fault, during the Middle Miocene in a similar manner as the Zarand, Beiuş basins and the basins in the basement of the Great Hungarian Plain (Györfi \& Csontos, 1994) (fide Csontos, 1995). Borod Basin represents in fact one of the eastern gulfs of the Pannonian Basin.

Several papers approaching the Neogene lithology and fauna in the eastern part of Borod Basin, which also indicated the age of the deposits, were published in the last six decades. The basin evolution took place under peculiar conditions to as compared the basins in the neighborhood, leading to the development of atypical faunal assemblages. These particularities resulted in long discussions over the age of the Neogene succession. Complex studies on the deposits in the Eastern part of Borod Basin were made by Givulescu (1957), Nicorici et al., (1977), Marinescu et al., (1980), and Papaianopol et al., (1984). Beside these studies, other papers dealt with the associated fauna and their ages (Paucă 1954; Paucă, 1969; Nicorici, 1970; Istocescu et al., 1970; Şuraru \& Şuraru, 1973; Istocescu \& Istocescu, 1974; Chintăuan, 1977; Şuraru et al., 1978; Moisescu, 1990, 1990a, 1991, 1992). During that period, terms like "horizon" and "level" were used to describe beds showing a distinctive lithological character.

\footnotetext{
1 "Babeş-Bolyai" University, Department of Geology, Kogălniceanu 1, 3400 Cluj Napoca,
} Romania 
In order to compare these deposits with similar ones in other regions, we define new formal lithostratigraphic units according to the international stratigraphic recommendations.

The definition of the formal lithostratigraphic units involves the establishment of stratotypes showing the whole lithologic succession of the respective unit. The outcrops offered such facilities, but when they were missing, geological boreholes or mining works were used. In the eastern part of Borod Basin the outcrops show only partly the Neogene succession. The lack of outcrops showing the complete succession - as an ideal case - leaded to the selection of some composite stratotypes. The holostratotypes were defined on the base of outcrops, while the supplementary stratotypes (parastratotypes) were based on geological boreholes performed in the area of coal exploration. The boreholes were made by S.C. Transgex S.A. Cluj-Napoca (formerly IPEG Cluj). The core samples and the primary documentation (core profiles, and geophysical diagrams) are preserved at the same institution. The collected and studied malacological material is stored in the Museum of Paleontology-Stratigraphy of the "Babeş-Bolyai" University in ClujNapoca.

\section{LITHOSTRATIGRAPHICAL UNITS}

1. Borod Formation nomen novum (= "gray sandy marls horizon with cerites and Ammonia", Nicorici et al., 1977; ="Valea Cetea Beds", Moisescu, 1990)

Borod Formation corresponds to the deposits previously defined by Moisescu (1990) as "Valea Cetea Beds" in the boreholes on Cetea Valley. The author briefly described the succession and did not define a stratotype. Taking these observations into account, we considered that it is possible to define a stratotype on Lupului Brook to clarify the lithological background of the formation. The stratotype is located on the territory of Borod locality; thus this name was given to the corresponding deposits.

Definition: gray to blackish silty, fine micaceous, fossiliferous marls and clays interlayered with silts, sands, sandstones, microconglomerates and coal.

Lower boundary: unconformity with the crystalline schists of the Someş Group, corresponding to a significant hiatus (Late Cretaceous-Early Miocene).

Upper boundary: disconformity with the greenish clays and sandstones belonging to the Cornițel Formation. Unfortunately based on our paleontological data we can not precisely prouve the extend of the gap between this unit and the following one.

Stratotype of a composite nature.

The Holostratotype (fig. 1) is located on Lupului Brook, at about $150 \mathrm{~m}$ east from the junction with Băița Valley (Lat. $47^{\circ} 10^{\prime} 30^{\prime \prime}$ / Long. $\left.22^{\circ} 36^{\prime} 30^{\prime \prime}\right)$.

The succession, starting from the brook bottom is shown in fig. 2 : 
- 1m greenish, locally to green clay containing a coal lens;

$-1 \mathrm{~m}$ greenish sandy clay;

- 0,5 m grayish fossiliferous marl;

$-1 \mathrm{~m}$ coarse micaceous sands with thin interbeddings of yellowish-red-dish clays;

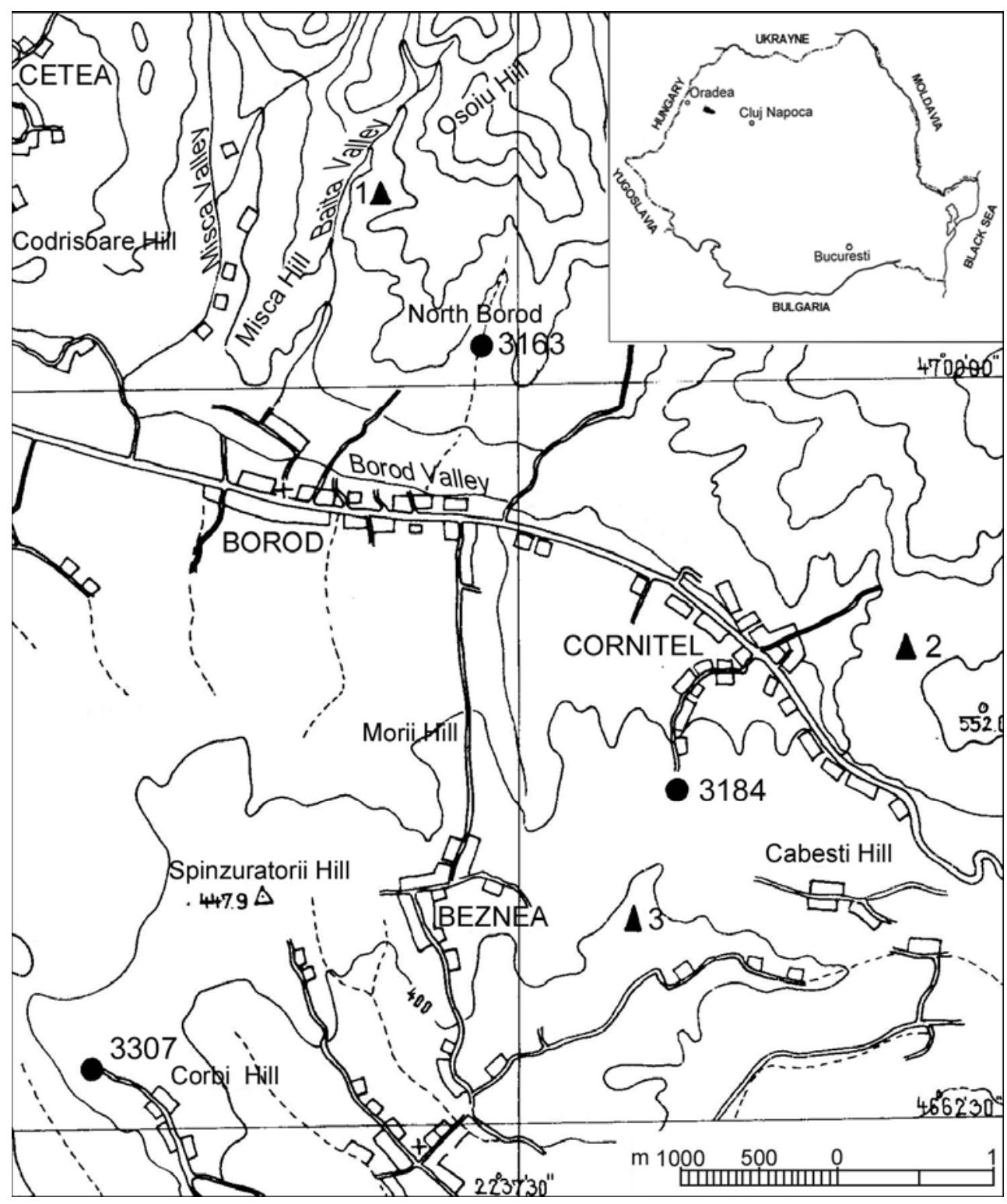

Fig.1 Location of the stratotypes: 1. Lupului Brook (Borod Formation); 2. Plopilor Hill (Cornițel Formation); 3. Ogăşoaia Brook (Beznea Formation) 
The outcrop shows the lower part of the formation, and no lower boundary stratotype can be defined there.

Parastratotype: Borehole 3163 , located north of Borod village, on Albului Brook (Lat. $47^{\circ} 00^{\prime} 30^{\prime \prime}$ / Long. $\left.22^{\circ} 37^{\prime} 00^{\prime \prime}\right)($ fig. 1). The cores are stored at SC Transgex SA Cluj - Napoca. It was made in 1991 at the depth of $380,00 \mathrm{~m}$ and at the altitude of $376,00 \mathrm{~m}$. The complete succession of Borod Formation can be studied between 368,00164,00m (204,00m) (fig. 2).

Extension of the formation: at the surface, the deposits belonging to Borod Formation represent a $250-300 \mathrm{~m}$ wide band between Cetea and Răchiții Valleys, on the border of mesometamorphic rocks and of the rhyolites from Plopiş Mountains. These deposits were intercepted in the boreholes south of the Cornițel fault, which is parallel to the Borod Valley. In the eastern sector, the deposits were intercepted in boreholes up to the junction between Borod and Cornițel valleys. It is supposed that the deposits are extended eastwards up to Hăituri Brook. In this area no outcrops or boreholes support this hypothesis. Eastward from this limit, the core samples definitely show younger deposits belonging to Cornitel Formation, which transgressively overlay the crystalline rocks of Someş Group. Westwards, the deposits of this formation were identified in boreholes down to Gheghie. The thickness of the deposits ranges between 100 to $240 \mathrm{~m}$.

Fossiliferous content: The macrofauna collected from the deposits of Borod Formation is rich and diverse as compared to the macrofauna present in the rest of the Neogene succession. It is represented mainly by gastropods, bivalves and scaphopods (Şuraru \& Şuraru, 1973; Nicorici et al., 1977; Moisescu, 1990, 1990a, 1991, 1992; Popa et al., 1997; Popa, 1998, 1998a; Popa et al., 1999). In addition to foraminifers and ostracods were also identified (Şuraru \& Şuraru, 1973; Gabos in Nicorici et al., 1977; Olteanu \& Popescu in Papaianopol et al., 1984).

The sediments in the lower part of the formation contain a brackish marine assemblage with Crassostrea gryphoides aginensis (TOURNOUIER), Pirenella plicata div. ssp. and Tympanotonos margaritaceus grateloupi ORBIGNY, taxa that were noticed in Central Paratethys only until the Eggenburgian. At the top of the 
formation a normal marine assemblage with taxa characterizing exclusively the Badenian deposits was identified: Parvicardium subhispidum (HILBER), Cerithiopsis tubercularis astensis COSSMANN, Bela sparsa (BOETTGER), Odostomia dispar BOETTGER, O. perrara BOETTGER, Eulimella nitidissima (MONTAGU), E. conulus EICHWALD, Chrysallida interstincta (MONTAGU), C. sacyi (COSSMANN \& PEYROT), Turbonilla scala (EICHWALD), and Ringicula costata (EICHWALD).

Besides fauna, in the boreholes from Borozel a sporopollinic association dominated by Juglandaceans (Petrescu \& Nicorici, 1977) and calcareous nannoplankton were identified. The nannoplankton assemblage is generally scarce. Helicosphaera ampliaperta the index species for NN4 zone was identified in the intervals of the marine mollusk asemblages (Chira in Popa et al., 1997; Popa \& Chira, 1999).

Age: Eggenburgian-Badenian.

2. Cornițel Formation nomen novum (= "greenish sandy-clayey complex" and "horizon of marls interlayered with coal and a mixed fauna", Nicorici et al., 1977)

Definition: gray compact marls (with fossiliferous layers and with carbonate laminae at the top) with clays, sandstones, microconglomerates - all having a green colour - and coal interbeddings.

Lower boundary: disconformity with the silty, fossiliferous gray marls and clays of the underlying Borod Formation or unconformity with the metamorphic rocks and Mesozoic deposits located in the eastern extremity of the basin.

Upper boundary: a disconformity-type of contact with the white-yellowish marls belonging to the Beznea Formation at the top (Bessarabian - Pannonian B).

Stratotype of a composite type.

Holostratoype located at Cornițel, on the northern slope of Plopilor Hill (Lat. $46^{\circ} 86^{\prime} 15^{\prime \prime} /$ Long. $22^{\circ} 39^{\prime} 30^{\prime \prime}$ )(fig. 1). From the base of the formation the following deposits were identified (fig. 3 ):

- 1,20m greenish clayey sandstones;

- 2,50m greenish clays;

$-1,50 \mathrm{~m}$ coal;

- 9,50m compact fossiliferous grayish marls;

The above mentioned succession represents the lower and middle part of the formation, without the lower boundary stratotype.

Parastratotype: Borehole 3184, located in the southwestern part of Cornițel village, it was made in 1990 , at the depth of $411,00 \mathrm{~m}$ and is located at the altitude of $432 \mathrm{~m}$ (Lat. $46^{\circ} 79^{\prime} 30^{\prime \prime} /$ Long. $22^{\circ} 38^{\prime} 15^{\prime \prime}$ )(Fig.1). The cores are stored at SC Transgex SA Cluj - Napoca.

The borehole passed through the deposits of this formation between 410 to 100m (310m)(fig. 3).

Extension: The deposits belonging to Cornițel Formation outcrop on the northern and eastern border of the basin, where the blocktype structure lead to the uplift of these deposits at the surface. Southwards, the deposits of Beznea Formation transgressively overlay the Formation. The boreholes intercepted these sediments approximately in the northern half of the basin, from Cornițel up to Gheghie and Luncşoara. 
MIRELA POPA

Fossiliferous content. The fauna associated to the deposits of Cornitel Formation is represented by gastropods, bivalves and foraminifers (Givulescu, 1957; Nicorici et al., 1977; Şuraru et al., 1978; Marinescu et al., 1980; Papaianopol et al., 1984; Popa, 1998a). The assemblages arew poor as number of species but are quantitatively well represented at certain levels.

The compact gray marls overlaying the coal contains a reduced salinity assemblage with Congeria from the group ornithopsis. Greenish clays, sandstones and microconglomerates with a typical brackish association of Pirenella picta develops at the top of these marls, which pleads for a Early Sarmatian age.

At Borod and Luncşoara, one of the richest Sarmatian macrofloral assemblage from Transylvania was identified (Givulescu in Şuraru et al., 1978; Givulescu 1991). The sporopollinic assemblage described by Petrescu \& Nicorici (1977) is also consistent; some of the elements persist also at the base of the Pannonian deposits.

Also, north-eastern of Luncşoara was described an assemblage of calcareous algae (Bucur et al, 1993).
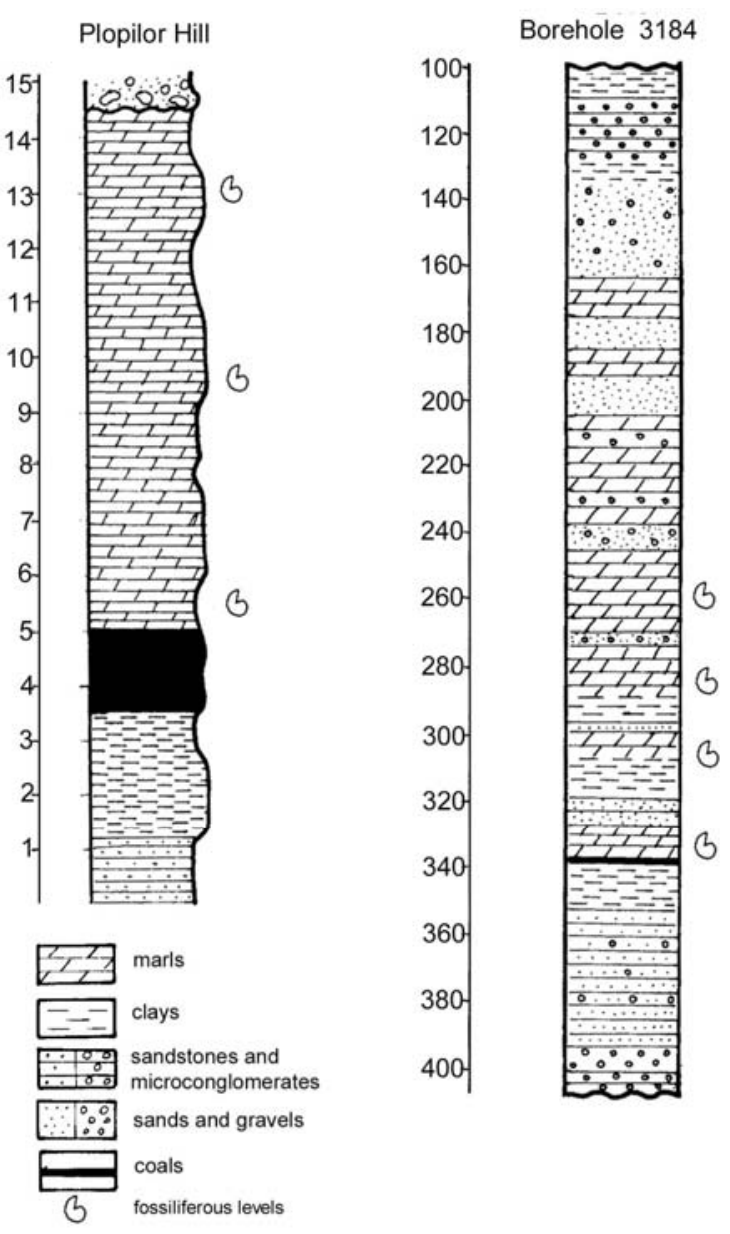

Age: Early Sarmatian (Volhynian).

2.1. Borozel Member nomen novum (="coal level", Nicorici et al., 1977)

Definition: two coal beds separated by a tuffite interbed.

Lower boundary: gradual transition, from greenish clays to blackish clays and coal. We suggest that the lower boundary should be drawn at the basal part of the first coal bed.

Upper boundary: a sharp contact with the compact fossiliferous gray marls.

Stratotype: Borehole 322 is located in Borozel village, southwest from the mine (Lat. $47^{\circ} 02^{\prime} 30^{\prime \prime} /$ Long. $\left.22^{\circ} 33^{\prime} 00^{\prime \prime}\right)$. The cores are stored at SC Transgex SA Cluj - Napoca. It was drilled during year 1982, it has a depth of $340,00 \mathrm{~m}$ and a surface altitude of $278 \mathrm{~m}$. This unit can be studied between $\mathrm{m} 275,80-287,10$ (fig. 4). 


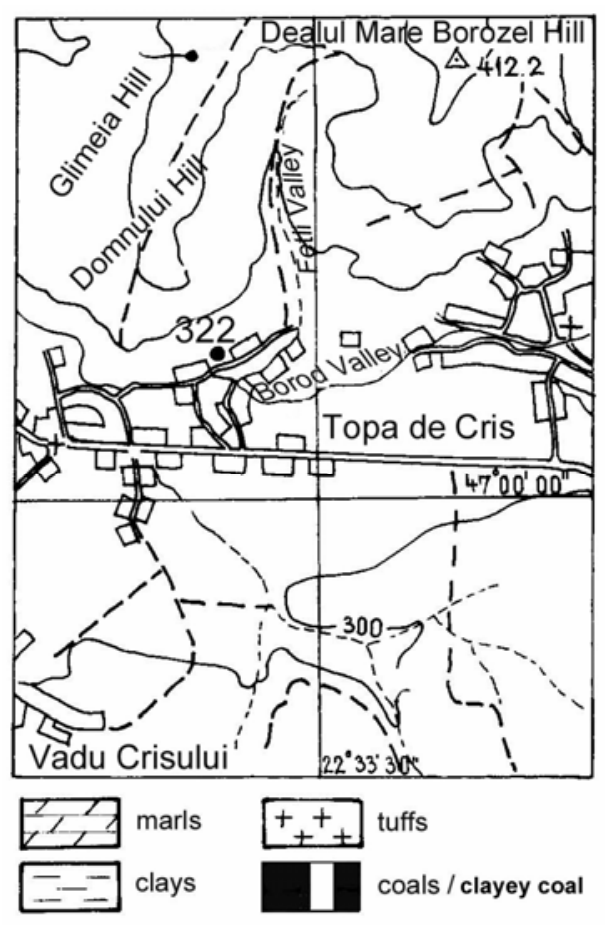

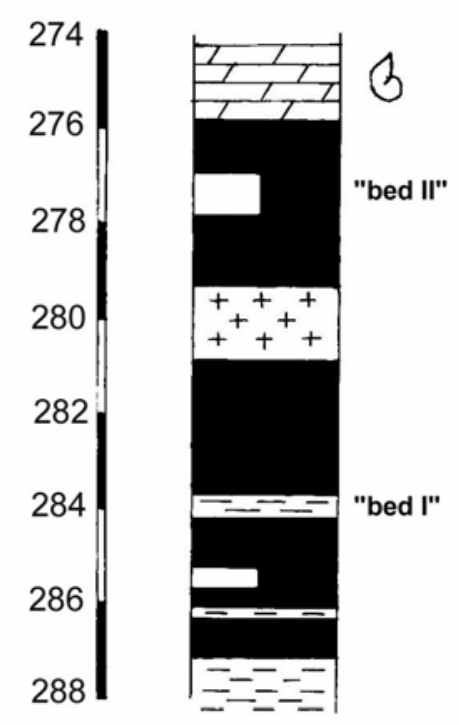

Borehole 322

Fig. 4. Location of the type section and the sedimentary log of Borozel Member

It was considered that an underground stratotype is more suggestive in case of this low rank unit, even if the coal beds partly develop at the surface in Plopilor and Popii Hills (Cornițel). Most of the information on this lithostratigraphical unit is given by the core samples from the boreholes made in the eastern part of the basin in order to describe the geometrical and qualitative features of coal beds.

Extension: The deposits belonging to Borozel Member can be identified in boreholes in the northern part of the basin, starting from Cornițel to Borod, Borozel, Gheghie and Lunç̧oara.

The coal "bed I" (in fact it is a succesion of coal beds separated by thin sterile beds) is located at the lower part of the unit and is represented by one to three beds of coal separated by greenish to blackish clay, carbonatic clays or even tuff interbeddings. The sterile interbeds are thin in the areas with the maximum development of coal beds; their thickness progressively increases on in spite of the coal beds to the sides. The total thickness of this coal bed (coal beds + sterile interbeds) may reach 7-8m, or even $14 \mathrm{~m}$ (borehole 3175).

Within the "bed I", the upper coal bed shows the greatest extension and thickness. In the western part of the area (Gheghie, Luncşoara) it is decimetric, near Topa de Criş, Borozel, Valea Mare it reaches 3-4 m or even 5-6 m southwest from Borod, while towards east, the thickness is decimetric again; the bed disappears towards Cornitel. The next two coal beds extend over reduced areas, especially around Borozel, Topa de Criş and Valea Mare localities, being generally less than $1 \mathrm{~m}$ thick but exceptionally showing 1-2 $\mathrm{m}$. 
The "bed II" is the most extended one. It is located at the top of the "bed I", of which is separated by a tuffitic intercalation and it develops continuously from east (Cornițel) to west (Gheghie). The "Bed II" consists mainly of a single bed. It only differs towards peripheral areas, being built-up by two or more (3-4) thin coal beds separated by tuffitic or clayey interbeds and the coal beds gradually disappearing.

The thickness of "bed II" varies from several decimeters in west and north to 5-6 m in the central and western part, near ValeaMare, Borozel, and Topa de Criş villages.

"Bed I" and "bed II" are separated by a benchmark represented by a tuffitic intercalation $0.5-3 \mathrm{~m}$ or sometimes even 5-6 $\mathrm{m}$ thick consisting of a light grayish or even whitish rhyodacitic vitroclastic tuff (Mureşan et al., 1986).

Age: Early Sarmatian (Volhynian).

\section{Beznea Formation nomen novum}

Definition: grayish whitish or yellowish compact marls that can be easily cleaved.

Lower boundary: disconformity -type contact with the gray marls and carbonate laminae belonging to Cornițel Formation, while in the southern part of the basin it shows an unconformity-type contact with the Mesozoic deposits (Bessarabian Pannonian B zone).

Upper boundary: partly the contact with Quaternary deposits.

Stratotype of a composite nature.

Holostratotype is located on Ogăşoaia Brook, which is a right tributary of Beznea Valley (Lat. $46^{\circ} 72^{\prime} 30^{\prime \prime} /$ Long. $22^{\circ}$ 38' 00") (fig. 1). The succession consists of (fig. 5):

$-5 \mathrm{~m}$ gray whitish marls;

$-0,50 \mathrm{~m}$ tuff;

$-4,00 \mathrm{~m}$ whitish compact marls which cleave easily;
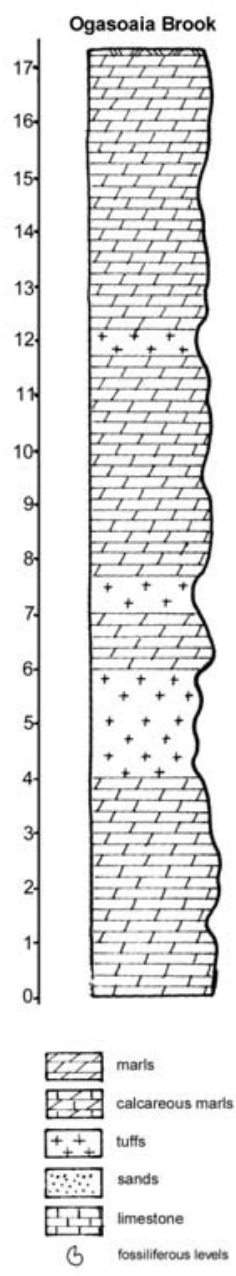

Fig. 5. Type section of Beznea Formation

$-0,70 \mathrm{~m}$ coarse tuffaceous sand;

$-1,00 \mathrm{~m}$ grayish-whitish laminated;

$-2,00 \mathrm{~m}$ gray tuff;

$-4,00 \mathrm{~m}$ whitish fine sandy marls;

The succession of deposits in the outcrop represent the lower part of the lithologic column of the formation. The stratotype does not show the lower boundary of the formation. 
Parastratotype: Borehole 3307 is located west of Beznea village, between Fînațe and Corbani valleys (Lat. $46^{\circ} 63^{\prime} 00^{\prime \prime} /$ Long. $22^{\circ} 35^{\prime} 10^{\prime \prime}$ ) (fig. 1). The cores are stored at SC Transgex SA Cluj - Napoca. It was made in year 1994, at the depth of $445,00 \mathrm{~m}$ and the altitude of $416,00 \mathrm{~m}$. The complete succession of this formation can be followed in the interval 444,00-600,00m (438,00m) (fig. 5).

Extension: the deposits of Beznea Formation outcrop from the southern areas of the basin (Bratca, Beznea), up to the northern part near Borod and Cornițel; they are only partly covered by the Quaternary deposits. Westwards, the deposits are extended down to Vadu Crişului and Gheghie. The thickness varies from tens of meters in the northern part of the basin to thousands of meters in the central and southern parts. The most significant thickness was recorded southwest from Borod, at the $\mathrm{m} 500$ in borehole 3070 respectively (Nicorici et al., 1977).

Fossiliferous content: A reduced number of taxa, but in the same time a significant number of specimens at certain levels characterize the faunal assemblage. It consists by Congeria czjzeki (M. HOERNES), Pisidium sp., Orygoceras fuchsi fuchsi (KITTL), Gyraulus sp., Stenothyrella ovoidea, Hydrobia sp. and Limnocardiidae. Beside the mollusks, a large number of ostracods are also present. These species were mentioned also by Givulescu (1957), Nicorici (1970), Nicorici et al.(1977), Chintăuan (1977) and Papaianopol et al. (1984).

The presence of taxa of Orygoceras fuchsi and Congeria czjzeki pleads for a Pannonian age of the deposits (according to the biozonation system used for Vienna Basin, Papp, 1951) (fide Papp, 1985), namely for the C-E Pannonian zones. The faunal elements characterizing the Lower Pannonian are missing, thus the disconformity between the Sarmatian and Pannonian deposits is once again emphasized.

The Pannonian deposits macroflora collected from Cornițel, Borod, Beznea and Valea Crişului contains numerous taxa among which some represent new species (Givulescu, 1974, 1975, 1975a, 1976, 1991). The deposits of Beznea Formation also contain a rich microfloral association (Petrescu \& Nicorici, 1977).

Age: Pannonian (C-E zones).

\section{Acknowledgements}

Thanks are due to Dr. Sorin Filipescu for the critical review of the manuscript and to Dr. Dana Pop for the English translation.

\section{REFERENCES}

1. Balintoni, I., 1997, Geotectonica terenurilor metamorfice din România. Editura Carpatica, 176 p, Cluj - Napoca.

2. Bucur, I., Nicorici, E., Şuraru, N., 1993, Sarmatian calcareous algae from Romania. Bull. Soc. Paleont. Ital. Vol I, p 81-91, 4 pl., 2 text fig., Modena.

3. Chintăuan, I., 1977: Studiul ostracodelor din sedimentele neogene de la Delureni (Bazinul Borod), Nymphaea, Muz. Țării Crişurilor, V, p.63-69, 1 pl., 1 tab., 1 fig., Oradea.

4. Csontos, L., 1995: Tertiary tectonic evolution of the Intra - Carpathian area: areview. Acta Vulcanologica, 7 (2), p. 1 - 13, 11 fig. 
5. Dimitrescu, R., 1988: Note sur la structure du cristallin "autochtone" du Gilău de sud-ouest. D. S. Inst. Geol.72-73/5 (1985; 1986), p.75-83, 1 fig., Bucureşti.

6. Givulescu, R., 1957: Cercetări geologice in bazinul neogen al Borodului (Reg. Oradea). Acad. RPR Cluj, Stud. Cerc. St., Geol. - Geogr., VIII/ 1-2, p. 99-158, 20 fig., Cluj.

7. Givulescu, R., 1974: Asupra vârstei unor flore fosile neogene din depresiunea Borod. D. S. Inst. Geol., LX/4 (1972 - 1973), p. 115 - 120, Bucureşti.

8. Givulescu, R., 1975: Plantes fossiles du Pannonien de Delureni, Roumanie. Palaeontographica B, 153/ 4 - 6, p. $150-182,4$ fig., 13 pl., Stuttgart.

9. Givulescu, R., 1975a: Plantes fossiles du Pannonien inférieur de Valea de Criş (BihorRoumanie). Acta Palaeobotanica, XVI /1, p. 71-82, 7 fig., 7 pl., Krakow.

10. Givulescu, R., 1976: O nouă contribuție la cunoaşterea florei fosile de la Cornițel (Bihor). Nymphaea, Muz. Țării. Criş., IV, p. 59 - 66, 5 fig., Oradea.

11. Givulescu, R., 1991: Plante fosile din forajul 3153 de la Borod, jud. Bihor. Edit. Acad., Stud. şi cerc., 36, p. $73-76,2$ pl., 1 fig., Bucureşti.

12. Istocescu, D., Mihai, A., Diaconu, M., Istocescu, F., 1970: Studiul geologic al regiunil cuprinse între Crişul Repede şi Crişul Negru. D. S. Inst. Geol.LV/5 Tect. Geol. Reg., (1967 - 1968), p. 89 - 106, 1 pl., Bucureşti.

13. Istocescu, D., Istocescu, F., 1974: Consideratii geologice asupra depozitelor neogene ale bazinului Crişurilor. Stud. Cerc. Geol.geogr. geof. (Geol.), Acad. RSR, 19, p. 115 - 127, Bucureşti.

14. Marinescu, FL., Bițoianu, C., Olteanu, R., Papaianopol, I., Popescu, A., Rădan, S., RoggeȚăranu, E., Țicleanu, N., 1980: Raport - Studiul geologic complex al formațiunilor neogene din partea de vest a bazinului Borod în vedera stabilirii condițiilor de acumulare a cărbunilor, Arhiva Transgex, Cluj - Napoca.

15. Moisescu, V., 1990: Mollusques miocenes du Basin de Borod, D. S. Inst. Geol. Geofiz., vol. 74/3 (1987), 1990, p. 169 - 194, 2 fig., 11 pl., Bucureşti.

16. Moisescu, V., 1990a: Remarque sur la faune de molluque aquitaniens du bassin de Borod, Studia, Univ. Babeş - Bolyai, XXXV/2, p.89-96, Cluj-Napoca.

17. Moisescu, V., 1991: Nouvelles espèces des mollusques miocènes dans le bassin de Borod. Studia Univ. Babeş-Bolyai, Geol., XXXVI, 1, p. 93-96, 3 fig., Cluj-Napoca.

18. Moisescu, V., 1992: L'etude de la variabilité du groupe Pirenella du Bassin de Borod, Rom. J. of Paleontology, 75, p. 13 - 18, 6 fig., 1 pl., Bucureşti.

19. Mureşan, I., Ghergari, L., Bedelean, I., 1986: Contribution a la petrographie des tufs vulcaniques des formations neogenes du Bassin de Vad - Borod. Studia Univ. BabeşBolyai, Geol.-Geogr., XXXI, 1, 67p., Cluj-Napoca.

20. Nicorici, E., 1970: Creseis borodiana Paucă sau Orygoceras fuchsi (Kittl). Bull. Ştiinț. (Biol., Fiz., Chim., Matem.), Inst. Ped., II, p.123-127, pl.2, Baia - Mare

21. Nicorici, E., Mureşan, I., Duşa, A., Petrescu, J., Bedelean, I., Ghergari, L., Băluță, C., Gabos, L., 1977: Studiul biostratigrafic şi petrografic al formațiunilor neogene din perimetrul Borozel bazinul Borodului, Arhiva Transgex, Cluj - Napoca.

22. Papaianopol, I., Bițoianu, C., Costea, C., Dumitrică, P., Jipa, D., Macaleț, R., Marinescu, FL., Moisescu, V., Olteanu, R., Ponta, Gh., Popescu, A., Rădan, S., Rogge, E., Roman, Şt., Țicleanu, N. 1984: Studiul complex al Bazinului Borod din punct de vedere al genezei şi acumulării cărbunilor; redactarea hărții humitogenetice, Arhiva Transgex, Cluj-Napoca.

23. Papp, A., 1985: Die Schichtenfolgen des Pannonien in den Randgebieten der Zentralen Paratethys. Wiener Becken-Anteil in Österreich. In vol. " Cronostratigraphie und Neostratotypen " Miozän (M6) - Pannonien, p. 59-63, 1 fig., 1 tab., Budapest.

24. Paucă, M., 1954: Neogenul din bazinele externe ale Munților Apuseni. Anuar. Com. Geol., XXVII, p. 259 - 336, Bucureşti.

25. Paucă, M., 1969: Creseis borodiana n.sp. de pteropod din bazinul Vadului. D.S. Com. Stat. Geol., Inst., Geol., LIV/2, (1966-1967), p.25-29, 1 fig., Bucureşti. 
26. Petrescu, I., Nicorici, E., 1977: Contribuții biostratigrafice la cunoaşterea formațiunilor neogene din Bazinul Borod (sector Borozel). Nymphaea, Muz. Țării Criş., V, p.37-52, 1 fig., 9 pl., Oradea.

27. Popa, M., Chira, C., Meszaros, N., 1997: Miocene molluscs and nannoplankton of the eastern part of the Borod depression, Univ. Bucureşti, Acta Paleontologica Romaniae (1997), 1, p. 129 - 133, 3 fig, 3 pl, Bucureşti.

28. Popa, M., 1998: Importanța biostratigrafică a ostreidelor din estul Depresiunii Borod, Studia Univ. Babeş-Bolyai, Geol., X LIII, 2, p. 41-56, 1 fig., 1tab., 6pl., Cluj-Napoca.

29. Popa, M., 1998a: Biostratigrafia depozitelor neogene din partea estică a Bazinului VadBorod. Teză de doctorat, 248 p., 31 pl., Cluj-Napoca.

30. Popa, M., Chira, C. 1999: Miocene Mollusk and calcareous Nannoplankton assemblages from the Borod Formation (Borod Basin, Romania).Sub tipar.

31. Şuraru, M., Şuraru, N., Givulescu, R., 1978: Sarmațianul din Valea Băița com. Borod şi paleoflora lui. Nymphaea, Muz. Țării Criş., VI, p.65-92, 2 fig., 9 pl., Oradea

32. Şuraru, N., Şuraru, M., 1973: Asupra prezenței miocenului inferior în bazinul Borod (Bihor). Studia Univ. Babeş-Bolyai, Geol-Min., XVIII/2, p. 29 - 38, 1 tab., 1 fig., Cluj. 